OPEN ACCESS

Edited by:

Ioannis Zabetakis,

University of Limerick, Ireland

Reviewed by:

Paola Roggero,

IRCCS Ca 'Granda Foundation

Maggiore Policlinico Hospital, Italy

Markus Xie,

Genentech, United States

${ }^{*}$ Correspondence:

Elena Camelia Berghea

bcamelia@gmail.com

Specialty section:

This article was submitted to

Nutritional Immunology,

a section of the journal

Frontiers in Immunology

Received: 31 January 2021 Accepted: 10 March 2021

Published: 07 April 2021

Citation:

Vassilopoulou E, Feketea G, Koumbi L, Mesiari C, Berghea EC and

Konstantinou GN (2021)

Breastfeeding and COVID-19:

From Nutrition to Immunity.

Front. Immunol. 12:661806.

doi: 10.3389/fimmu.2021.661806

\section{Breastfeeding and COVID-19: From Nutrition to Immunity}

\author{
Emilia Vassilopoulou ${ }^{1}$, Gavriela Feketea ${ }^{2,3}$, Lemonica Koumbi ${ }^{1}$, Christina Mesiari ${ }^{1}$, \\ Elena Camelia Berghea ${ }^{4,5 *}$ and George N. Konstantinou ${ }^{6}$
}

1 Department of Nutritional Sciences and Dietetics, International Hellenic University, Thessaloniki, Greece, ${ }^{2}$ PhD School, "Iuliu Hatieganu" University of Medicine and Pharmacy, Cluj-Napoca, Romania, ${ }^{3}$ Department of Pediatrics, Pediatric Allergy Outpatient Clinic, "Karamandaneio", Children Hospital, Patras, Greece, ${ }^{4}$ Department of Pediatrics, Allergology and Clinical Immunology Outpatient Clinic, Clinical Hospital of Emergency for Children MS Curie, Bucharest, Romania, ${ }^{5}$ Department of Pediatrics, Carol Davila University of Medicine and Pharmacy, Bucharest, Romania, ${ }^{6}$ Department of Allergy and Clinical Immunology, 424 General Military Training Hospital, Thessaloniki, Greece

Breastfeeding not only provides the optimum source of nutrients for the neonate and its first strong shield against infection but also lays the foundation for somatic and psychological bonding between the mother and child. During the current COVID-19 pandemic, although the guidelines of the relevant international and national agencies recommend breastfeeding by SARS-CoV-2-infected mothers, considerable insecurity persists in daily clinical practice regarding the safety of the infants and the perceived advantages and disadvantages of discontinuation of breastfeeding. This is a systematic review of the currently available information regarding the transmissibility of SARS-CoV-2 through or while breastfeeding and the protection against infection that breast milk might provide. The accumulated body of knowledge regarding the role of breast milk in the development of the neonatal immune system and protection against infection by other respiratory viruses is discussed, with a focus on the anti-inflammatory role of the antibodies, microbes, and viruses provided to the infant in breast milk and its relevance to the case of SARS-CoV-2.

\footnotetext{
Keywords: antibodies, anti-inflammation, breastfeeding, COVID-19, SARS-CoV-2, microbiome, virome, respiratory infection
}

\section{HIGHLIGHTS}

- Nature has designed the mother's breast milk to nurture the neonate and to protect of the dyad in "psyche and soma", ensuring the transfer of antibodies, microbes, and viruses, but also emotional stimulation.

- Since SARS-CoV-2 is highly transmissible, breastfeeding should be encouraged, but observing all appropriate safety measures, for the mother and close contacts

- With the vaccination schedule in progress, the pregnant mothers-to-be should probably be prioritized. 


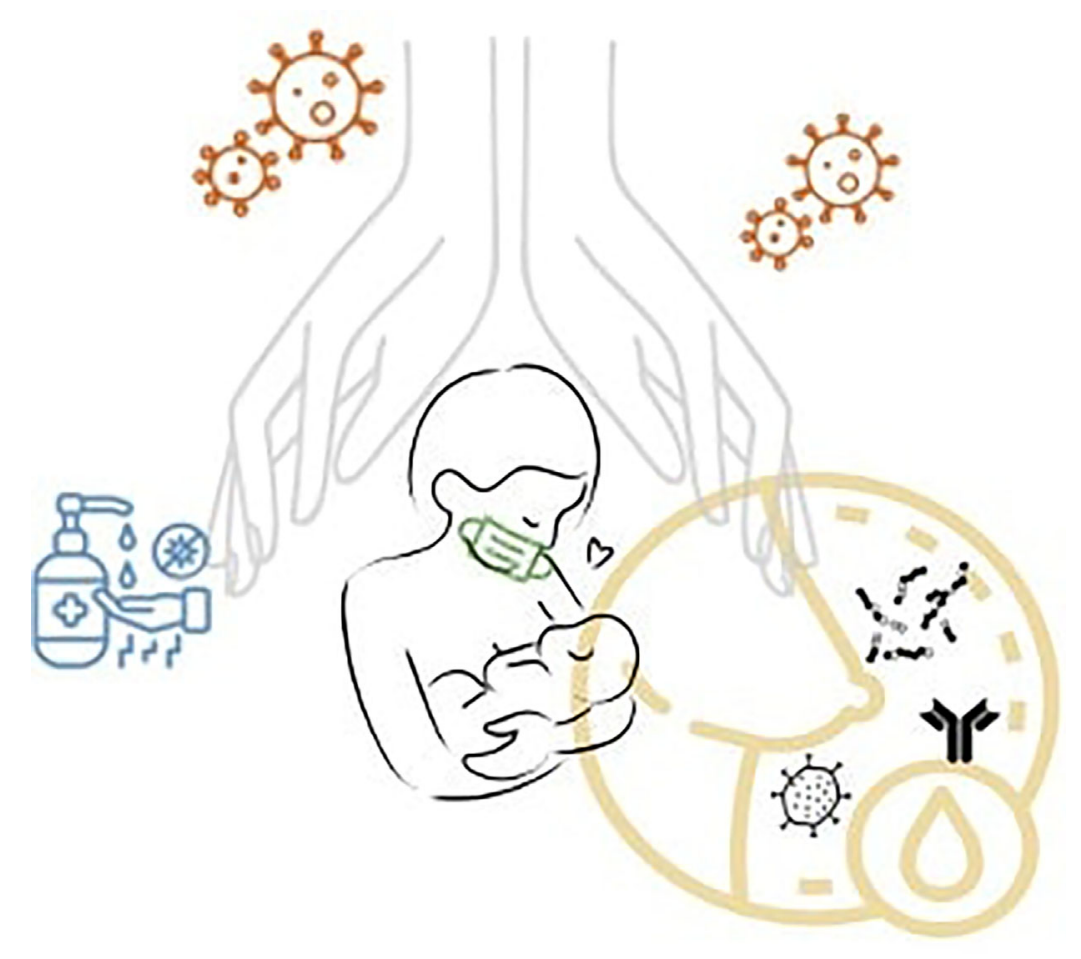

GRAPHICAL ABSTRACT

\section{BRIEF HISTORICAL PERSPECTIVE}

Since the beginning of 2020, when the World Health Organization (WHO) announced a new strain of coronavirus, the SARS-CoV-2, which provokes coronavirus disease 19 (COVID-19) (1), the whole world has been dominated by the COVID-19 pandemic. In January 2021, only 1 year later, approximately 85 million cases had been confirmed, resulting in more than 1.8 million deaths (2).

During the same period, approximately 140 million births have been registered (3) and a great dilemma arose regarding the possible need to discontinue the breastfeeding of infants of infected mothers (4). Although, to date, evidence on the risk of vertical transmission, via the respiratory tract or through the breast milk itself, is limited, breastfeeding has generally been accepted as the preferred nutrition for the infant of the infected mother. In breast milk from infected mothers, IgA antibodies against SARS-CoV-2 have been detected, which may account for the reduced clinical impact of the disease in breastfed infants upon future viral exposure (5).

This mini-review summarizes the current evidence, collected in a systematic literature search and narrative review of original articles related to breastfeeding by SARS-CoV-2-infected mothers, and deploying knowledge gained from other respiratory virus-transmitted diseases about the protective antiinflammatory effects of breastfeeding. The specific questions addressed in the review were whether or not the infant should be breastfed when (1): the mother is diagnosed with SARS-CoV2 before or immediately after delivery; (2) the lactating mother is positive for SARS-CoV-2 but the infant is negative; (3) both mother and infant are positive for SARS-CoV-2; (4) or the mother is negative but the infant is positive for SARS-CoV-2, based on evidence from the literature and knowledge gained from other respiratory virus infections.

\section{METHODS}

The review followed the Preferred Reporting of Systematic Reviews and Meta-Analysis (PRISMA) guidelines to collect articles on breastfeeding by SARS-CoV-2-infected mothers (6). This review was not registered with PROSPERO, which does not currently accept registration of reviews.

We searched the PubMed, Scopus, Web of Science, and MedRxiv electronic databases up to December $31^{\text {st }} 2020$ to identify original published studies describing lactating women with a confirmed diagnosis of COVID-19, using the following search keywords and phrases: ("COVID-19" OR "2019-nCoV" OR "novel coronavirus" OR "SARS-CoV-2" OR "coronavirus 2") AND breastfeeding. Reference tracking was carried out to identify other studies eligible for inclusion.

Each reference retrieved was screened independently by two researchers, following predefined criteria to determine eligibility for the systematic review. Studies were excluded if: 1. they did not involve humans (e.g., in vitro or animal research), and 2. they were non-original articles (e.g., book chapters, review articles, metanalysis, guidelines). There were no date or language restrictions on the search. 
All the original observational studies, case reports and case series of breastfeeding women diagnosed with COVID-19 identified in the search were included. In view of the heterogeneity observed across the studies, it was decided to perform a narrative synthesis, using the Synthesis Without Meta-analysis (SWiM) reporting guidelines (intended to complement the PRISMA guidelines) (7). Descriptive statistics were presented (frequency and proportions) based on the total cases with available information. In addition, the current guidelines issued by international and national health organizations were retrieved and summarized. Documentation on other maternal respiratory viral infections and breastfeeding was gathered and the evidence on the potential protective effect of breastfeeding for the infants is presented and discussed.

\section{SUMMARY OF THE ESTABLISHED PRINCIPLES}

\section{Current Recommendations About Breastfeeding and COVID-19}

Human breastfeeding enhances both maternal and infant health, with a dynamic, bidirectional exchange between the mother and the infant, which constitutes the cornerstone of infant and child well-being.

Despite concerns of transmission from the infected mother to the infant, global and national health stakeholders have so far univocally encouraged breastfeeding during the COVID-19 pandemic. The WHO (8), the United Nations International Children's Emergency Fund (UNICEF) (9), the Union of European Neonatal \& Perinatal Societies (UENPS) (10), and the US Centers for Disease Control and Prevention (CDC) (11), all highlight the well-established overall short- and long-term immunological and psychosomatic benefits of breastfeeding for the dyad. The current recommendations point out that there is, at present, insufficient evidence about the transmission of COVID-19 through breastfeeding. For this reason, strict measures of mother-infant separation and discontinuation of breastfeeding are to be avoided, regardless of a positive diagnosis and the intensity of symptoms, unless the severity is of such a level that the mother cannot take care of the infant, in which case, expressed, fresh, unpasteurized breast milk should be provided for the baby (8).

In spite of these guidelines, there has considerable scepticism during the pandemic among the front-line healthcare professionals, gynecologists, midwives, and pediatricians, on whether they should encourage the infected mother to breast feed her baby (12).

\section{STUDIES RELATED TO BREASTFEEDING OF SARS-COV-2-INFECTED MOTHERS}

From the search in the four electronic databases, 537 articles were retrieved, and after removal of duplicates, 383 were screened. Among 46 articles reaching the final assessment for eligibility, 18 were excluded, as they did not meet all inclusion criteria, i.e., they did not provide data on whether the mother and/or infant was infected, whether the infant was breastfeeding and what practices were used. Finally, 21 case reports and 7 original articles, published up until December $31^{\text {st }} 2020$ were included, originating mainly from China (11 case reports; 1original article) and Italy ( 2 case reports; 2 original articles). Figure 1 presents the process of inclusion of studies in the review.

For purposes of this review the studies were sub-grouped into four categories according to the infected member of the dyad, and the measures undertaken are discussed accordingly. A summary of the 28 studies is presented in Table $\mathbf{1}$.

\section{SARS-CoV-2-Positive Mother Before or on Delivery}

Some mothers were prohibited from holding the neonates, in order to minimize the risk of infection $(36,39)$ and expressed breast milk was proposed as the optimum feeding solution (38). Mothers in a good clinical condition were encouraged to breastfeed, with all appropriate instructions and precautions (37). In the case of admission of preterm infants to the neonatal intensive care unit (NICU), expressed breast milk was suggested, if available (36). Overall, among the 231 births from SARS-CoV-2-positive mothers, 13 neonates $(5.8 \%)$ tested positive within the first 48 hours of life $(31-34,36,38,39)$.

\section{SARS-CoV-2-Positive Lactating Mother, With Negative Infant}

Generally, breastfeeding was encouraged $(13,14,17,23,24,26)$, but in order to reduce the risk of infection $(36,39)$, instructions for appropriate precautions were given (37). Measures undertaken to minimize the risk of transmission during breastfeeding were mask wearing, handwashing, routine cleaning and disinfection of all surfaces touched, thorough cleaning and sterilization of infant feeding equipment before and after use, breast washing with gauze saturated with soap and water, and avoidance of falling asleep with the baby $(13,14,17)$. Alternatively, expression of breast milk and feeding of the infant by a healthy family member or a caretaker was recommended (19). In some cases, when feeding became a controversial issue, the parents were to allowed decide if the infant would be breast fed, due to the insecurity caused by the perceived risk of transmission to the infant $(16,22)$. Insecurity about the decision was increased when SARS-CoV-2 was traced in the breast milk, in which case, breastfeeding was suspended and could be resumed after a period of isolation, followed by a confirmed negative test on the mother $(15,20)$. Of a total of 63 women, $37(58.7 \%)$ discontinued breastfeeding and were isolated from their babies. Of over 38 samples of breast milk tested in SARS-CoV-2-positive mothers, only $2(5.2 \%)$ were positive for SARS-CoV-2 $(16,24)$.

\section{Both Mother and Infant SARS-CoV-2-Positive}

Breastfeeding was strongly encouraged where both members of the dyad were positive $(27,30,31)$, and further investigation was suggested on the role of IgG antibodies (27) in the possible 


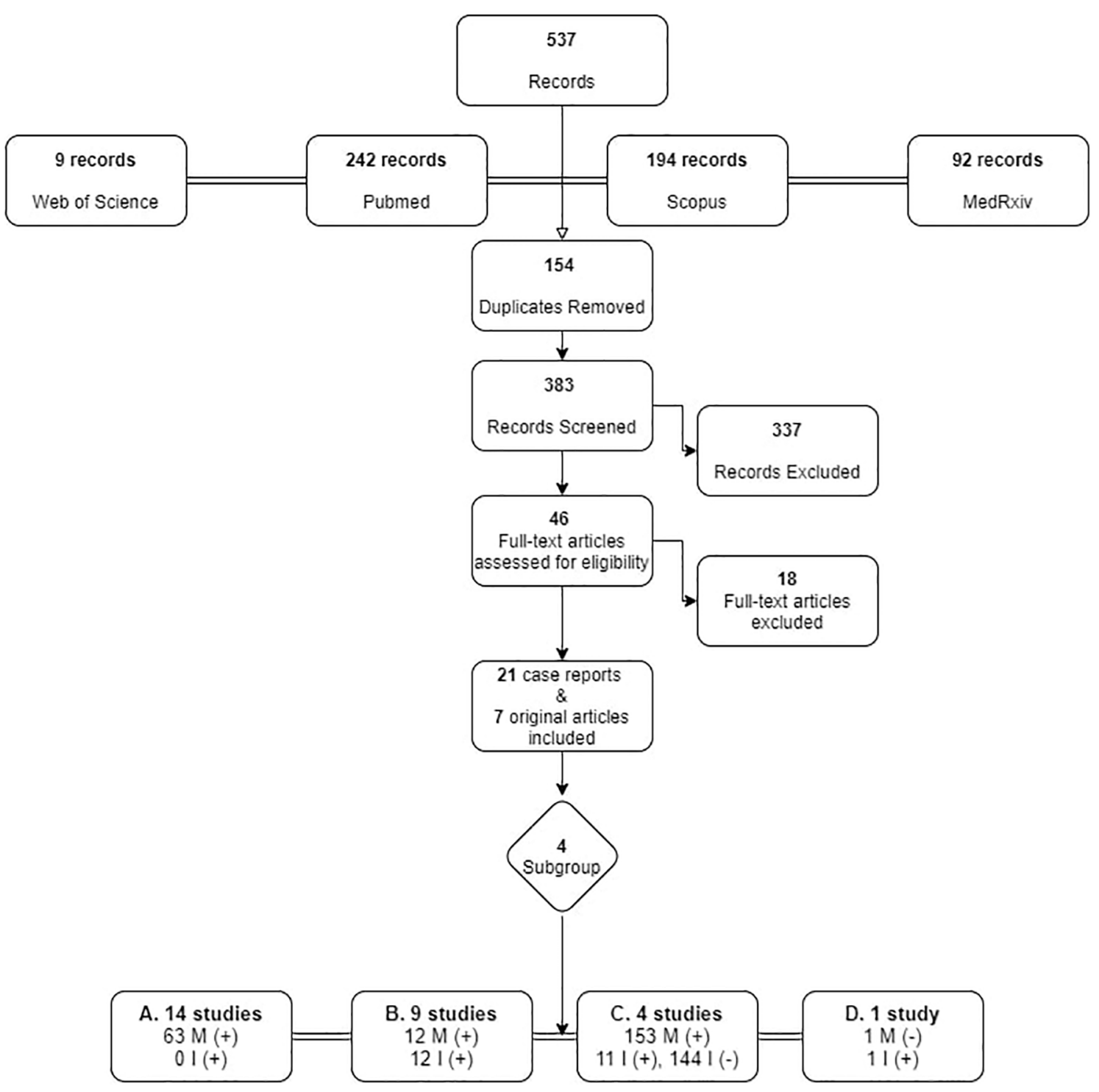

FIGURE 1 | Search strategy flowchart for original articles on breastfeeding and SARS-Cov-2. M, Mother; I, Infant. +: SARS-CoV-2 infected, -: negative for SARS-CoV-2.

protective role of breast milk antibodies on the immunity of the infants $(33,35)$. Among the breast milk samples tested for SARSCoV-2, 27\% (3/11) were positive $(27,28,30,34,35)$, but the milk was not considered to be the cause of infection of the infants (29).

\section{HEALTHY MOTHER AND INFANT SARS-COV-2-POSITIVE INFANT}

In the one reported case of an infected infant with a healthy mother, the mother was encouraged to remain in quarantine with her baby and to continue breastfeeding. Despite the close contact, the mother remained negative for SARS-CoV-2 (40).

\section{THE CURRENT "STATE OF THE ART"}

\section{The Anti-Inflammatory Effects of Breastfeeding: Knowledge Gained From Other Respiratory Viruses}

Respiratory infections are a leading cause of morbidity in children. During the first year of life, breastfeeding provides protection from these infections, dependent on its duration (41), mainly against lower respiratory infection. The immaturity of the infant's immune system at birth increases the risk of infection by external agents, including viruses and bacteria (42), which is related to the unpreparedness of the neonatal respiratory and gastrointestinal (GI) tracts to resist invasion. 
TABLE 1 | Studies included in the review of breastfeeding (BF) and SARS-CoV-2 infection ( $N=28$ ).

\begin{tabular}{|c|c|c|c|c|c|c|c|c|c|c|c|c|}
\hline Authors & Year & Country & Study Type & $\begin{array}{l}\text { No of } \\
\text { infected } \\
\text { mothers }\end{array}$ & $\begin{array}{l}\text { Mother's age } \\
\text { (years) }\end{array}$ & $\begin{array}{l}\text { Infant's } \\
\text { Age } \\
\text { (months) }\end{array}$ & Mother's Symptoms & $\begin{array}{c}\text { Infant's } \\
\text { Symptoms/test }\end{array}$ & Feeding mode & $\begin{array}{l}\text { Maternal } \\
\text { Separation } \\
\text { (Y, yes/N, } \\
\text { no) }\end{array}$ & $\begin{array}{c}\text { SARS- } \\
\text { CoV-2 in } \\
\text { breastmilk }\end{array}$ & Conclusion \\
\hline \multicolumn{13}{|c|}{ A. Infected mother-non-infected infant } \\
\hline Lowe and Bopp (13) & 2020 & Australia & Case report & 1 & 31 & $<1$ & Fever \& respiratory symptoms & $(-)$ & $\mathrm{BF}$ & N & N/A & \multirow{4}{*}{$\begin{array}{l}\text { BF \& room-in with precautions } \\
\text { BF with precautions, Upon } \\
\text { maternal isolation: feeding with } \\
\text { pasteurized DHM or IF until BF } \\
\text { is resumed } \\
\text { BF after isolation and negative } \\
\text { test, } \mathrm{PBM} \text { during isolation } \\
\text { Decision about BF by parent \& } \\
\text { doctor }\end{array}$} \\
\hline Pereira et al. (14) & 2020 & Spain & $\begin{array}{l}\text { Retrospective } \\
\text { case series }\end{array}$ & 22 & $34(19-43)$ & $<1$ & $\begin{array}{l}50 \% \text { symptomatic (6 mild } \\
\text { symptoms, } 5 \text { pneumonia) }\end{array}$ & $(-)$ & $\begin{array}{l}20 / 22 \mathrm{BF} \\
2 / 22 \mathrm{IF}\end{array}$ & $\begin{array}{l}9 / 11 \\
\text { symptomatic } \\
\text { mothers } \\
\text { isolated }\end{array}$ & N/A & \\
\hline Lang and Zhao (15) & 2020 & China & Case report & 1 & 30 & $<1$ & Dry cough & $(-)$ & $\mathrm{BF}$ after isolation & Y & $(-)$ & \\
\hline Bastug et al. (16) & 2020 & Turkey & Case report & 1 & 20 & $<1$ & Asymptomatic & $(-)$ & $\begin{array}{l}\text { PBF, When } \\
\text { SARS-CoV-2 } \\
\text { detected in BM- } \\
\text { BF discontinued }\end{array}$ & Y & $(+)$ & \\
\hline Gabriel et al. (17) & 2020 & Spain & $\begin{array}{l}\text { Observational } \\
\text { prospective } \\
\text { study }\end{array}$ & 7 & $33.4(31-37)$ & $<1$ & $\begin{array}{l}6 / 7 \text { asymptomatic } 1 / 7 \text { fever, } \\
\text { myalgia, malaise, headache }\end{array}$ & $(-)$ & $\mathrm{BF}$ & N/A & $(-)$ & $\begin{array}{l}\text { Direct BF safe or hand: } \\
\text { expressed BM with precautions }\end{array}$ \\
\hline Chu et al. (18) & 2020 & China & Case report & 1 & 30 & $<1$ & $\begin{array}{l}\text { Gastrointestinal symptoms, } \\
\text { fever }\end{array}$ & $(-)$ & PBM & Y & $(-)$ & $\begin{array}{l}\text { SARS-CoV-2 rarely transmitted } \\
\text { through BM- possible induction } \\
\text { of passive immunity via lgG }\end{array}$ \\
\hline Liu et al. (19) & 2020 & China & Case report & 1 & 37 & 6 & $\begin{array}{l}\text { Fever, cough, sore throat, } \\
\text { fatigue }\end{array}$ & $(-)$ & $\begin{array}{l}\text { BF discontinued } \\
\text { after mother's } \\
\text { positive test }\end{array}$ & Y & N/A & $\begin{array}{l}\text { PBM and feeding to infant by a } \\
\text { healthy caretaker/family member }\end{array}$ \\
\hline Feng et al. (20) & 2020 & China & Case report & 1 & 33 & 2 & Fever & $(-)$ & $\begin{array}{l}\text { Suspended BF } \\
\text { after diagnosis }\end{array}$ & $\mathrm{Y}$ & $\mathrm{N} / \mathrm{A}$ & $\mathrm{BF}$ temporal suspension \\
\hline Perrone et al. (21) & 2020 & Italy & Case report & 1 & N/A & $<1$ & fever, anosmia, \& malaise & $(-)$ & $\begin{array}{l}\mathrm{BF}+\text { expressed } \\
\text { maternal milk }\end{array}$ & $\mathrm{N}$ & $(-)$ & $\begin{array}{l}\text { BF with precautions when virus } \\
\text { is not traced in milk }\end{array}$ \\
\hline Liu et al. (22) & 2020 & China & $\begin{array}{l}\text { Prospective } \\
\text { study }\end{array}$ & 19 & $31(27-34)$ & $<1$ & $\begin{array}{l}\text { fever }(11 / 19), 5 / 19 \text { cough or } \\
\text { dyspnea, } 2 / 19 \text { diarrhea or } \\
\text { another gastrointestinal } \\
\text { symptom }\end{array}$ & $(-)$ & Term Formula & $\mathrm{Y}$ & $(-)$ & $\begin{array}{l}\text { Not vertical transmission with } \\
\mathrm{BF}\end{array}$ \\
\hline Dong et al. (23) & 2020 & China & Case report & 1 & 33 & $<1$ & Cough \& chest tightness & $(-)$ & $\mathrm{BF}$ & $\mathrm{Y}$ & $(-)$ & IgG \& IgA of BM might provide \\
\hline Zhu et al. (24) & 2020 & China & Case report & 5 & $32(27-34)$ & $<1$ & $\begin{array}{l}\text { Main symptoms: fever, chest } \\
\text { distress or dyspnea, cough, } \\
\text { nasal congestion, rhinorrhea, } \\
\text { poor appetite, or diarrhea }\end{array}$ & $(-)$ & N/A & N/A & $1 / 5(+)$ & $\begin{array}{l}\text { Generally BF encouragement } \\
\text { but when SARS-CoV-2 BM } \\
\text { increased risk of transmission }\end{array}$ \\
\hline Dong et al. (25) & 2020 & China & Case report & 1 & 29 & $<1$ & $\begin{array}{l}\text { Fever, nasal congestion, } \\
\text { respiratory difficulties }\end{array}$ & $(-)$ & N/A & Y & $(-)$ & \multirow{2}{*}{$\begin{array}{l}\text { When increased IgG \& IgM } \\
\text { levels-infection at delivery } \\
\text { cannot ruled out } \\
\text { mother-to-child transmission is } \\
\text { unlike. }\end{array}$} \\
\hline Li et al. (26) & 2020 & China & Case Report & 1 & 30 & $<1$ & Dry cough, fever & $(-)$ & N/A & Y & $(-)$ & \\
\hline \multicolumn{13}{|c|}{ B. Infected mother-Infected infant } \\
\hline Yu et al. (27) & 2020 & China & Case report & 1 & 32 & 13 & Nasal congestion & $\begin{array}{l}{ }^{(+)} \\
\text {Fever, dry cough, nasal } \\
\text { congestion }\end{array}$ & $\begin{array}{l}\text { Directly BF \& } \\
\text { complementary } \\
\text { after } 6 \text { months }\end{array}$ & $\mathrm{N}$ & $(-)$ & BF safe \\
\hline \multirow[t]{2}{*}{ Groß et al. (28) } & \multirow[t]{2}{*}{2020} & \multirow[t]{2}{*}{ Germany } & \multirow[t]{2}{*}{ Case series } & \multirow[t]{2}{*}{2} & \multirow[t]{2}{*}{ N/A } & \multirow[t]{2}{*}{$<1$} & \multirow[t]{2}{*}{ Mild symptoms } & $(+)$ & $\mathrm{BF}$ & $\mathrm{N}$ & $\begin{array}{l}\text { Mother's } 1 \\
(-)\end{array}$ & \multirow{2}{*}{$\begin{array}{l}\text { BF with precautions/further } \\
\text { investigation on virus } \\
\text { transmission potential during BF }\end{array}$} \\
\hline & & & & & & & & $\begin{array}{l}\text { Respiratory, breathing } \\
\text { symptoms icterus }\end{array}$ & & & Mother's 2 & \\
\hline Tam et al. (29) & 2020 & Australia & Case series & 1 & 40 & 8 & $\begin{array}{l}\text { Sore throat, myalgia, productive } \\
\text { cough, fever }\end{array}$ & 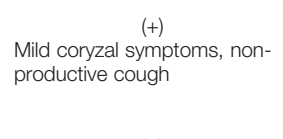 & $\begin{array}{l}\text { BF discontinued } \\
\text { and PBM when } \\
\text { infant was } \\
\text { confirmed with } \\
\text { COVID-19 }\end{array}$ & $\mathrm{N}$ & $\begin{array}{l}(+) \\
(+)\end{array}$ & $\begin{array}{l}\text { In infected infants BF should be } \\
\text { continued/nil adverse effects/ } \\
\text { SARS-CoV-2 RNA in breast } \\
\text { milk sample did not indicate } \\
\text { viable virus }\end{array}$ \\
\hline Salvatori et al. $(30)$ & 2020 & Italy & Case report & 2 & $31(26-36)$ & $<1$ & $\begin{array}{l}50 \% \text { anosmia \& dysgeusia, } \\
50 \% \text { back \& thoracic pain }\end{array}$ & $\begin{array}{l}\stackrel{(+)}{ } \\
50 \% \text { asymptomatic } \\
50 \% \text { diarrhea, cough, poor }\end{array}$ & BF & $\mathrm{N}$ & $(-)$ & $\begin{array}{l}\text { BF supported, transmission } \\
\text { more possibly through } \\
\text { respiratory droplets }\end{array}$ \\
\hline Phadke et al. (31) & 2020 & India & Case report & 1 & 33 & $<1$ & Asymptomatic & $\begin{array}{c}(+) \\
\text { asymptomatic }\end{array}$ & $\begin{array}{l}\text { IF } \\
\text { After positive test } \\
\text { for infant: direct } \\
\text { BF }\end{array}$ & Y & N/A & BF \& room-in with precautions \\
\hline
\end{tabular}


TABLE 1 | Continued

\begin{tabular}{|c|c|c|c|c|c|c|c|c|c|c|c|c|}
\hline Authors & Year & Country & Study Type & $\begin{array}{l}\text { No of } \\
\text { infected } \\
\text { mothers }\end{array}$ & $\begin{array}{l}\text { Mother's age } \\
\text { (years) }\end{array}$ & $\begin{array}{c}\text { Infant's } \\
\text { Age } \\
\text { (months) }\end{array}$ & Mother's Symptoms & $\begin{array}{c}\text { Infant's } \\
\text { Symptoms/test }\end{array}$ & Feeding mode & $\begin{array}{l}\text { Maternal } \\
\text { Separation } \\
\text { (Y, yes/N, } \\
\text { no) }\end{array}$ & $\begin{array}{l}\text { SARS- } \\
\text { CoV-2 in } \\
\text { breastmilk }\end{array}$ & Conclusion \\
\hline Kirtsman et al. (32) & 2020 & Canada & Case report & 1 & 40 & $<1$ & $\begin{array}{l}\text { myalgia, decreased appetite, } \\
\text { fatigue, dry cough \& fever }\end{array}$ & $\begin{array}{l}\qquad(+) \\
\text { Neutropenic, mild } \\
\text { hypothermia, feeding } \\
\text { difficulties \& hypoglycemic } \\
\text { episodes }\end{array}$ & $\mathrm{BF}$ & $\mathrm{N}$ & $(+)$ & $\begin{array}{l}\text { Further studies to neonates are } \\
\text { needed to identify transmission } \\
\text { routes }\end{array}$ \\
\hline $\begin{array}{l}\text { Hinojosa-Velasco et } \\
\text { al. (33) }\end{array}$ & 2020 & Mexico & Case report & 1 & 21 & $<1$ & $\begin{array}{l}\text { Cough, odynophagia, } \\
\text { headache, diarrhea, rhinorrhea, } \\
\text { sore throat, fever }\end{array}$ & $\begin{array}{l}\text { (+) newborn jaundice, } \\
\text { tachypnea, hypernatremia, } \\
\text { central cyanosis, dyspnea, and } \\
\text { oxygen saturation of less than } \\
92 \%, \text { (NICU) }\end{array}$ & $\begin{array}{l}\text { Synthetic milk } \\
\text { formula }\end{array}$ & $\mathrm{Y}$ & $(+)$ & BF might be protective \\
\hline Wang et al. (34) & 2020 & China & Case report & 1 & 34 & $<1$ & $\begin{array}{l}\text { Fever, vaginal bleeding, lower } \\
\text { abdominal pain }\end{array}$ & $(+)$ & Infant Formula & $\mathrm{Y}$ & $(-)$ & No $B F$ \\
\hline Fan et al. (35) & 2020 & China & Case series & 2 & $31.5(29-34)$ & $<1$ & $\begin{array}{l}\text { 1: Nasal congestion, fever } \\
\text { 2: fever, nasal congestion, sore } \\
\text { throat }\end{array}$ & $\begin{array}{l}\qquad(+) \\
\text { 1: fever and abdominal } \\
\text { distension with lymphopenia } \\
\text { 2: mild neonatal pneumonia } \\
\text { and lymphopenia }\end{array}$ & IF & $1 / 2 Y$ & $(-)$ & $\begin{array}{l}\text { Low risk of vertical transmission } \\
\text { via BF, potential protective role } \\
\text { of passive antibodies }\end{array}$ \\
\hline \multicolumn{13}{|c|}{ C. Infected mother- both infected and non-infected infants } \\
\hline ElHalik et al. (36) & 2020 & $\begin{array}{l}\text { United } \\
\text { Arab } \\
\text { Emirates }\end{array}$ & $\begin{array}{l}\text { Retrospective } \\
\text { observational } \\
\text { study }\end{array}$ & 35 & $32(24-42)$ & $<1$ & Negative & 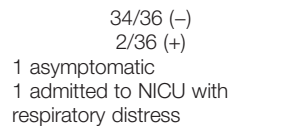 & $\begin{array}{l}32 / 36 \text { direct } \mathrm{BF} \\
\text { or } \mathrm{PBM}\end{array}$ & $\begin{array}{l}27 / 36 \\
\text { roomed-in }\end{array}$ & N/A & $\begin{array}{l}\text { Direct BF or PBM encouraged } \\
\text { with precautions }\end{array}$ \\
\hline Ronchi et al. (37) & 2020 & Italy & $\begin{array}{l}\text { Prospective } \\
\text { multicenter } \\
\text { study }\end{array}$ & 61 & $32(28-36)$ & $<1$ & $\begin{array}{l}\text { Symptoms at diagnosis: } 34 / 61 \\
\text { asymptomatic } \\
27 / 61 \text { at least } 1 \text { symptom }\end{array}$ & $\begin{array}{l}\quad \text { 0/62 on birth } \\
\text { 2/62 positive for SARS-CoV-2 } \\
\text { at } 7 \text { and 20d of life } \\
\text { respectively }\end{array}$ & $\begin{array}{l}\text { 45/62 Exclusive } \\
\text { BF } \\
13 / 62 \text { BF + IF } 3 / \\
62 \text { exclusive IF } 1 / \\
62 \mathrm{BF}+\text { PBM }\end{array}$ & $\begin{array}{l}51 / 52 \\
\text { roomed-in } \\
\text { exclusive BF }\end{array}$ & N/A & $\begin{array}{l}\text { BF and room-in encouraged to } \\
\text { infected mothers with good } \\
\text { clinical condition with } \\
\text { precautions }\end{array}$ \\
\hline Patil et al. (38) & 2020 & $\begin{array}{l}\text { United } \\
\text { States of } \\
\text { America }\end{array}$ & $\begin{array}{l}\text { Retrospective } \\
\text { cross- } \\
\text { sectional } \\
\text { study }\end{array}$ & 45 & $30(27.5-35.5)$ & $<1$ & $\begin{array}{l}\text { 27/45 asymptomatic } \\
16 / 45 \text { mild symptoms } \\
2 / 45 \mathrm{ICU}\end{array}$ & $\begin{array}{l}\text { 42/45 (+) SARS-CoV-2 } \\
\text { 3/45 -(+)/admitted to NICU- } \\
\text { asymptomatic }\end{array}$ & $31 / 33$ & $\begin{array}{l}33 / 45 \\
\text { roomed-in } \\
5 / 45 \\
\text { separated, } \\
7 / 45 \text { preterm } \\
\text { admitted to } \\
\text { NICU }\end{array}$ & $\begin{array}{l}\text { No tested } \\
\text { sample }\end{array}$ & $\begin{array}{l}\text { BF and room-in under proper } \\
\text { precautions }\end{array}$ \\
\hline Bertino et al. (39) & 2020 & Italy & $\begin{array}{l}\text { Prospective } \\
\text { Collaborative } \\
\text { Observational } \\
\text { Study }\end{array}$ & 12 & $30.5(24-38)$ & $<1$ & $\begin{array}{l}\text { 10/12 symptomatic: fever, } \\
\text { myalgia, rhinitis, cough, } \\
\text { dyspnea, sore throat, } \\
\text { conjunctivitis, diarrhea, chest } \\
\text { pain, anosmia, ageusia }\end{array}$ & $\begin{array}{l}\text { 4/12 (+) SARS-CoV-2 } \\
\text { asymptomatic }\end{array}$ & $\begin{array}{l}\text { 11/12 exclusively } \\
\mathrm{BF}\end{array}$ & No & $\begin{array}{l}11 / 12(-) \\
1 / 12(+)\end{array}$ & $\begin{array}{l}\text { BF or PBM (in isolation) } \\
\text { encouraged irrespective swab } \\
\text { test results with proper } \\
\text { precautions }\end{array}$ \\
\hline \multicolumn{13}{|c|}{ D. Non-infected mother-infected infant } \\
\hline Le et al. (40) & 2020 & Vietnam & Case report & $\begin{array}{l}1 \text { (non- } \\
\text { infected) }\end{array}$ & N/A & 3 & None $(-)$ & $\begin{array}{l}\text { (+) Rhinorrhea, nasal } \\
\text { congestion \& fever }\end{array}$ & Exclusively BF & No & $\begin{array}{l}\text { No tested } \\
\text { sample }\end{array}$ & $\begin{array}{l}\text { Need to further investigate } \\
\text { SARS-CoV-2 transmission } \\
\text { routes to pediatric population }\end{array}$ \\
\hline
\end{tabular}

$\overline{B F}$, breastfeeding; IF, infant formula; $Y$, yes; $n$, no; N/A, not available; DHA, donor human milk; PBM, pumped breast milk; PBF, pumped breastfeeding; BM, breast milk; (-), negative; (+), positive; NICU, neonatal intensive care unit. 
Breast milk changes in synthesis, from colostrum through a transitional stage to mature milk, ensuring appropriate nutrition for the infant (43). Intensive, continuing research has provided an appreciable body of documentation on the health benefits of breastfeeding for both mother $(44,45)$ and child. Regarding immunity, human milk induces in the infant the regulation and development of the innate (46) and adaptive immune systems $(47,48)$, with a major long-term role in health and disease (49).

The anti-inflammatory protection conveyed by breast milk is effected by both chemical components and cellular interactions. Colostrum and transitional milk safeguard the infant via an abundant glycoprotein, lactoferrin, which has multilevel actions, lymphostimulatory, anti-inflammatory, anti-bacterial, anti-viral and anti-fungal (50). Its protective functions are attributed to its iron-binding properties, inhibition of interleukin-1 $\beta$ (IL-1 $\beta$ ) and tumor necrosis factor-alpha (TNF- $\alpha$ ), stimulation of the activity and maturation of lymphocytes, and preservation of an antioxidant environment (51). Lactoferrin, along with other milk peptides protects against bacteria and fungus (52). In vitro studies have shown that lactoferrin inhibits the invasion and growth of respiratory syncytial virus (RSV), interacting directly with the F glycoprotein on the surface of the virus, which is essential for viral penetration. Adenovirus infection was also observed to be inhibited in vitro due to interference of lactoferrin with the primary receptors present at the cellular level. Milk regurgitation into the nose after breastfeeding has been suggested to increase phage adherence to mucosal surfaces in the respiratory tract, in addition to the gut, eliminating in this way mucosal bacteria and protecting against recurrent respiratory infections in breastfed infants, in the longer term (53).

New knowledge gained during the 2003 SARS-CoV-1 epidemic was that lactoferrin interacts with heparin sulphate glycosaminoglycan (HSPG) cell receptors, interfering with the first anchoring sites of the virus on the cell, and thus preventing the initial contact between the SARS-CoV and host cells. Lactoferrin has also been shown to block the interaction between spike viral protein and HSPC in an angiotensinconverting enzyme 2 (ACE2) receptor, which otherwise results in the full infection (54).

Other dominant oligosaccharides in human milk serve both as a direct barrier to pathogens and as a prebiotic, i.e., aliment for probiotics, which promote synthesis of a healthy microbiota (42). The binding capacity of the oligosaccharides has proven protective against viruses with high morbidity and mortality, including human immunodeficiency virus (HIV) (55) and rotavirus (56), and breast milk mucin is able to aggregate poxviruses prior to their entry into host cells (57).

Additional protective properties of breast milk are provided by the transfer of maternal immune cells to the infant, including macrophages, neutrophils and lymphocytes (58). The concentration of these cells in the human breast milk vary according to the age of the infant, taking into account that in the early stage of lactation, the neonatal immune system is completely immature (59). Thus, the proportion of the different leukocytes vary between colostrum (macrophages $40-$
50\%, neutrophils $40-50 \%$ and lymphocytes 5-10\%) and more mature milk (macrophages 85\%, lymphocytes 15\%).

The immune properties of the mother are also transferred to the breastfed infant in the form of secretory IgG (60) and IgA in maternal milk (61). Breast milk attains the highest concentration in IgG antibodies in the colostrum, and their concentration drops after the first month of life (62) and stops abruptly with weaning (63). IgG antibodies, transferred to the fetus through the placenta during intrauterine life and to the infant after birth in breast milk, constitute the infant's first defense system. In mothers immunized against RSV, s-IgG antibodies were detected in breastmilk (64), providing protection to the infant against the main cause of respiratory infection during the first year of life (65). IgA antibodies coat the GI and respiratory mucosa and block the entrance of foreign antigens (50) and viruses (63). In premature infants, the IgA levels are higher, for enhanced protection (66). In the event of an infection, in either the mother or the child (67), breast milk conveys a plethora of antipathogenic and anti-inflammatory bioactive factors (68) to protect the infant. In attacks by respiratory virus infections, such as RSV, protection is mediated by polymeric IgA antibodies to a protein of the RSV surface membrane, inhibiting virus replication (50).

In addition to the transfer of antibodies, human milk triggers immune-protective responses by the host. In influenza, type I interferons (IFN), cytokines with strong simultaneous anti-viral, pro-apoptotic and pro-inflammatory properties, are produced significantly more often in breastfed infants, transforming viral attacks to formes frustes (69).

Breastfeeding has been documented to exert more effective protection against a spectrum of pneumonia-causing viruses, including influenza, RSV and parainfluenza, in girls than in boys (70); these findings were interpreted by the researchers as a "nature"-provided advantage for survival of females, in order to preserve the species.

Protection against viral invasion appears to be enhanced by the regurgitation of breast milk into the upper respiratory tract, conveying viable commensal, mutualistic, and probiotic bacteria (71) and viruses (53) that colonize the upper respiratory tract, contributing to the maturation of the infant's immune system.

Bacteria in the human milk are one of the earliest sources of prokaryotic microorganisms transferred to the infant, following the maternal microbial colonization through the amniotic fluid, placenta and umbilical fluid (72), and a more substantial transmission of vaginal and gut microorganisms to the newborn through the birthing canal (73). The human milk microbiota (HMM) originates from the maternal GI tract and skin, and from the infant's mouth (71). HMM and other human milk components, such as human milk oligosaccharides (HMO), reflect environmental factors, e.g., viral exposure, weather, and diet, in addition to the immune status of the mother (74).

Human milk transmits a significant load of viruses, eukaryotic and bacteriophages, from the mother to the infant, which enhance the maturation of both innate and adaptive immune systems. Eukaryotic viruses may impact the health status directly, while bacteriophages act via the bacterial ecology. 


\section{HIGHLIGHTING FUTURE DIRECTIONS IN BREASTFEEDING RESEARCH}

In children, COVID-19 infection rates are lower than in adults, while fatality rates are almost zero (71). Children generally have milder symptoms, but there are reports of the development of a novel multisystem inflammatory syndrome in children (MIS-C) similar to Kawasaki disease, predicating continuous vigilance (53).

The current policy is that breastfeeding is contraindicated in only a limited number of viral diseases, i.e., HIV, cytomegalovirus (CMV) in preterm infants, and human Tlymphotropic virus I (72). As it constitutes an incomparable feeding method for babies, international and national health authorities strongly recommend exclusive breastfeeding for at least the first six months of life: "Breastfeeding is one of the most effective ways to ensure child health and survival" - WHO (8); "Low rates and early cessation of breastfeeding have important adverse health and social implications for women, children, the community and the environment, result in greater expenditure on national health care provision, and increase inequalities in health" - European Commission (EC) (75)“.

The unsurpassed benefits of breastfeeding include not only irreplaceable nutrition, ensuring healthy growth for the infant, but also prevention of obesity in later life (74). It is a mainstay for promoting the immune development of the infant by both immunological factors transferred from mother to infant through breast milk (76) and microorganisms colonizing the organs and viruses enriching the virome.

SARS-CoV-2 is probably transmitted in multiple ways, including through droplets via the respiratory tract and invasion by enterocytes (73). GI symptoms manifest first in infancy, and lactoferrin in breast milk has been suggested to be capable of strengthening junctions between microbes in the gut and thus amplifying the innate defense. Although at present, this is only an assumption for SARS-CoV-2, in other strains of SARS$\mathrm{CoV}$, lactoferrin was shown to increase mucosal immunity and prevent viral anchoring on cell receptors (77). Cytokines and growth factors in breast milk excite the infant's immune system

\section{REFERENCES}

1. The American Journal of Managed CareA Timeline of COVID-19 Developments in 2020 (2020). AJMC. Available at: https://www.ajmc.com/view/a-timeline-ofcovid19-developments-in-2020 [Accessed 2021, January 2].

2. World Health Organization. WHO Coronavirus Disease (COVID-19) Dashboard (2020). Available at: https://covid19.who.int/ [Accessed 2021, January 2].

3. World Mapper. Births 2020. (2020). Available at: https://worldmapper.org/ maps/births-2020/ [Accessed 2021, January 2].

4. Shuai WS, Zhou X, Guang LX, Yan LY, Li W, Sharifu LM, et al. Experience of Clinical Management for Pregnant Women and Newborns with Novel Coronavirus Pneumonia in Tongji Hospital, China. Curr Med Sci (2020) 40 (2):285-9. doi: 10.1007/s11596-020-2174-4

5. Lalaguna Mallada P, Díaz-Gómez NM, Costa Romero M, San Feliciano Martín L, Gabarrell Guiu C. Impacto de la pandemia de Covid-19 en la lactancia y cuidados al nacimiento. Importancia de recuperar las buenas prácticas. Rev Esp Salud Publica (2020) 94. and balance the anti-inflammatory and pro-inflammatory cytokines, lessening their effect and preventing the "cytokine storm" described in other viral infections, such as H1N1 'swine flu' and H5N1 'bird flu' (78).

The most abundant antibody in breast milk, sIgA, provides adequate specific protection against pathogens, among which also are viruses. The specificity of $\operatorname{sIgA}$ is determined by the immune response of the mother to previous infection, probably explaining the low rates of infection or milder symptoms of the infected breastfed infants of SARS-CoV-infected mothers. Concerning this phenomenon, the cases where infection is not protected against by breastfeeding should be considered. For example, in pertussis, the sIgA in the human milk of infected mothers was higher than in that of control subjects, but did not protect against infection of the infant, and therefore vaccination of pregnant women was recommended (79). The evidence to date on pregnant women infected by SARS-CoV-2 does not demonstrate a more severe or complex clinical picture than in the general infected population. Further investigation is needed to accumulate knowledge regarding anti-SARS-CoV-sIgA produced through breastfeeding for the neonate.

In view of the time-dependent protective effect of exclusive breastfeeding against viral infections, and the increased maternal contact of the breastfed infant compared with the infant receiving artificial or mixed feeding (41), and the high transmissibility of SARS-CoV, protective measures should be strictly observed for safeguarding the lactation process.

\section{AUTHOR CONTRIBUTIONS}

EV contributed to the conception, designed the review, and wrote the first draft. EV and GF collected the relevant literature and independently reviewed the studies, while GK further evaluated the studies where conflict was presented in the decision. EV, CM, LM, EB, and GK wrote sections of the manuscript. All authors contributed to the article and approved the submitted version.

6. PRISMA. [cited 2021 Jan 23]. http://www.prisma-statement.org/Protocols/ Registration

7. Campbell M, McKenzie JE, Sowden A, Katikireddi SV, Brennan SE, Ellis S, et al. Synthesis without meta-analysis (SWiM) in systematic reviews: Reporting guideline. BMJ (2020) 368:16890. doi: 10.1136/bmj.16890

8. Breastfeeding and COVID-19. [cited 2021 Jan 23]. Available at: https://www. who.int/news-room/commentaries/detail/breastfeeding-and-covid-19.

9. UNICEF. Infant and Young Child Feeding in the Context of COVID-19 (2020). Available at: https:/www.unicef.org/media/68281/file/IYCF-ProgrammingCOVID19-Brief.pdf. [Accessed 2021, January 2].

10. Davanzo R, Moro G, Sandri F, Agosti M, Moretti C, Mosca F. Breastfeeding and coronavirus disease-2019: Ad interim indications of the Italian Society of Neonatology endorsed by the Union of European Neonatal \& Perinatal Societies. Matern Child Nutr (2020) 16(3):e13010. doi: 10.1111/mcn.13010

11. Coronavirus Disease (COVID-19) and Breastfeeding | Breastfeeding | CDC.

12. Dimopoulou D, Triantafyllidou P, Daskalaki A, Syridou G, Papaevangelou V. Breastfeeding during the novel coronavirus (COVID-19) pandemic: guidelines and challenges. J Matern Neonatal Med (2020) 1-7. doi: 10.1080/ 14767058.2020.1838481 
13. Lowe B, Bopp B. COVID-19 vaginal delivery - A case report. Aust N Z J Obstet Gynaecol (2020) 60(3):465-6. doi: 10.1111/ajo.13173

14. Pereira A, Cruz-Melguizo S, Adrien M, Fuentes L, Marin E, Forti A, et al. Breastfeeding mothers with COVID-19 infection: a case series. Int Breastfeed $J$ (2020) 15(1):69. doi: 10.1186/s13006-020-00314-8

15. Jing LG, Zhao $\mathrm{H}$. Can SARS-CoV-2-infected women breastfeed after viral clearance? J Zhejiang Univ Sci B (2020) 21(5):405-7. doi: 10.1631/jzus.B2000095

16. Bastug A, Hanifehnezhad A, Tayman C, Ozkul A, Ozbay O, Kazancioglu S, et al. Virolactia in an Asymptomatic Mother with COVID-19. Breastfeed Med Off J Acad Breastfeed Med (2020) 15(8):488-91. doi: 10.1089/bfm.2020.0161

17. Gabriel MÁM, Martínez AMM, Martínez MEM, Pedroche JA. Negative Transmission of SARS-CoV-2 to Hand-Expressed Colostrum from SARSCoV-2-Positive Mothers. Breastfeed Med (2020) 15(8):492-4. doi: 10.1089/ bfm. 2020.0183

18. Chu H, Li J, Yan J, Bai T, Schnabl B, Zou L, et al. Persistent SARS-CoV-2 RNA Positive in Feces but Negative in Breastmilk: A Case Report of COVID-19 in a Breastfeeding Patient. Front Med (2020) 7(December):1-5. doi: 10.3389/ fmed.2020.562700

19. Liu X, Zhou L, Zhu Y. Report on a lactating patient with COVID-19. Infection (2020) 100:(0123456789). doi: 10.1007/s15010-020-01532-2

20. Feng Y, Li J, Wu J, Xia M, Xu W. Insight from a COVID-19-Infected Lactating Mother with A Healthy Breastfed Infant. Front Med Case Rep (2020) 01 (05):1-6. doi: 10.47746/FMCR.2020.1502

21. Perrone S, Giordano M, Meoli A, Deolmi M, Marinelli F, Messina G, et al. Lack of viral transmission to preterm newborn from a COVID-19 positive breastfeeding mother at 11 days postpartum. J Med Virol (2020) 92(11):23467. doi: $10.1002 / j \mathrm{mv} .26037$

22. Liu W, Wang J, Li W, Zhou Z, Liu S, Rong Z. Clinical characteristics of 19 neonates born to mothers with COVID-19. Front Med (2020) 14(2):193-8. doi: 10.1007/s11684-020-0772-y

23. Dong Y, Chi X, Hai H, Sun L, Zhang M, Xie WF, et al. Antibodies in the breast milk of a maternal woman with COVID-19. Emerg Microbes Infect (2020) 9 (1):1467-9. doi: 10.1080/22221751.2020.1780952

24. Zhu C, Liu W, Su H, Li S, Shereen MA, Lv Z, et al. Breastfeeding Risk from Detectable Severe Acute Respiratory Syndrome Coronavirus 2 in Breastmilk. J Infect (2020) 81(3):452-82. doi: 10.1016/j.jinf.2020.06.001

25. Dong L, Tian J, He S, Zhu C, Wang J, Liu C, et al. Possible Vertical Transmission of SARS-CoV-2 from an Infected Mother to Her Newborn. JAMA - J Am Med Assoc (2020) 323(18):1846-8. doi: 10.1001/jama.2020.4621

26. Li Y, Zhao R, Zheng S, Chen X, Wang J, Sheng X, et al. Lack of vertical transmission of severe acute respiratory syndrome Coronavirus 2, China. Emerg Infect Dis (2020) 26(6):1335-6. doi: 10.3201/eid2606.200287

27. Yu Y, Li Y, Hu Y, Li B, Xu J. Breastfed 13 month-old infant of a mother with COVID-19 pneumonia: a case report. Int Breastfeed J (2020) 15(1):68. doi: 10.1186/s13006-020-00305-9

28. Groß R, Conzelmann C, Müller JA, Stenger S, Steinhart K, Kirchhoff F, et al. Detection of SARS-CoV-2 in human breastmilk. Lancet (2020) 395 (10239):1757-8. doi: 10.1016/S0140-6736(20)31181-8

29. Tam PCK, Ly KM, Kernich ML, Spurrier N, Lawrence D, Gordon DL, et al. Detectable Severe Acute Respiratory Syndrome Coronavirus 2 (SARS-CoV-2) in Human Breast Milk of a Mildly Symptomatic Patient With Coronavirus Disease 2019 (COVID-19). Clin Infect Dis (2020) 60:465-6. doi: 10.1093/cid/ ciaa673/5848850

30. Salvatori G, De Rose DU, Concato C, Alario D, Olivini N, Dotta A, et al. Managing COVID-19-Positive Maternal-Infant Dyads: An Italian Experience. Breastfeed Med (2020) 15(5):347-8. doi: 10.1089/bfm.2020.0095

31. Phadke AK, Kumble A, Varghese A, Sherigar B, Reddy R. A case report of neonatal coronavirus disease-19 infection in South India. Indian J Case Rep (2020) 6(8):461-3. doi: 10.32677/IJCR.2020.v06.i08.014

32. Kirtsman M, Diambomba Y, Poutanen SM, Malinowski AK, Vlachodimitropoulou E, Parks WT, et al. Probable congenital sars-cov-2 infection in a neonate born to a woman with active sars-cov-2 infection. Cmaj (2020) 192(24):E647-50. doi: $10.1503 / \mathrm{cmaj} .200821$

33. Hinojosa-Velasco A, de Oca PVBM, García-Sosa LE, Mendoza-Durán JG, Pérez-Méndez MJ, Dávila-González E, et al. A case report of newborn infant with severe COVID-19 in Mexico: Detection of SARS-CoV-2 in human breast milk and stool. Int J Infect Dis (2020) 100:21-4. doi: 10.1016/j.ijid.2020.08.055
34. Wang S, Guo L, Chen L, Liu W, Cao Y, Zhang J, et al. A case report of neonatal 2019 coronavirus disease in China. Clin Infect Dis (2020) 71(15):853-7. doi: 10.1093/cid/ciaa225

35. Fan C, Lei D, Fang C, Li C, Wang M, Liu Y, et al. Perinatal Transmission of 2019 Coronavirus Disease-Associated Severe Acute Respiratory Syndrome Coronavirus 2: Should We Worry? Clin Infect Dis (2020) 395:1757-8. doi: 10.1093/cid/ciaa226/5809260

36. Saleh Elhalik M. Clinical profile of neonates delivered from mothers with confirmed COVID-19 infection: An experience from a Tertiary Perinatal Care Center in Dubai, UAE. J Pediatr Neonatal Care (2020) 10(4):128-30. doi: 10.15406/jpnc.2020.10.00427

37. Ronchi A, Pietrasanta C, Zavattoni M, Saruggia M, Schena F, Sinelli MT, et al. Evaluation of Rooming-in Practice for Neonates Born to Mothers with Severe Acute Respiratory Syndrome Coronavirus 2 Infection in Italy. JAMA Pediatr (2020) 4:405-6. doi: 10.1001/jamapediatrics.2020.5086

38. Patil UP, Maru S, Krishnan P, Carroll-Bennett R, Sanchez J, Noble L, et al. Newborns of COVID-19 mothers: short-term outcomes of colocating and breastfeeding from the pandemic's epicenter. J Perinatol (2020) 40(10):14558. doi: 10.1038/s41372-020-0765-3

39. Bertino E, Moro GE, De Renzi G, Viberti G, Cavallo R, Coscia A, et al. SARSCOV-2 IN HUMAN BREAST MILK AND NEONATAL OUTCOME - A. Lancet (2020) 61:2-8. doi: 10.2139/ssrn.3611974

40. Le HT, Nguyen LV, Tran DM, Do HT, Tran HT, Le YT, et al. The first infant case of COVID-19 acquired from a secondary transmission in Vietnam. Lancet Child Adolesc Heal (2020) 4(5):405-6. doi: 10.1016/S2352-4642(20) 30091-2

41. Pandolfi E, Gesualdo F, Rizzo C, Carloni E, Villani A, Concato C, et al. Breastfeeding and respiratory infections in the first 6 months of life: A case control study. Front Pediatr (2019) 7(APR):1582-90. doi: 10.3389/ fped.2019.00152

42. Newburg DS, Walker WA. Protection of the neonate by the innate immune system of developing gut and of human milk [Internet]. Pediatr Res (2007) 61:2-8. doi: 10.1203/01.pdr.0000250274.68571.18

43. Andreas NJ, Kampmann B, Mehring Le-Doare K. Human breast milk: A review on its composition and bioactivity. In: Early Human Development, vol. 91. US: Elsevier Ireland Ltd (2015). p. 629-35.

44. Ahn S, Corwin EJ. The association between breastfeeding, the stress response, inflammation, and postpartum depression during the postpartum period: Prospective cohort study. Int J Nurs Stud (2015) 52(10):1582-90. doi: 10.1016/ j.ijnurstu.2015.05.017

45. Kendall-Tackett K. A new paradigm for depression in new mothers: The central role of inflammation and how breastfeeding and anti-inflammatory treatments protect maternal mental health. Int Breastfeed J (2007) 2:419-45. doi: 10.1186/1746-4358-2-6

46. Iwasaki A, Medzhitov R. Control of adaptive immunity by the innate immune system. Nat Immunol (2015) 16:343-53. doi: 10.1038/ni.3123

47. Alexander KL, Targan SR, Elson CO. Microbiota activation and regulation of innate and adaptive immunity. Immunol Rev (2014) 260:206-20. doi: 10.1111/ imr. 12180

48. Pacheco AR, Barile D, Underwood MA, Mills DA. The impact of the milk glycobiome on the neonate gut microbiota. Annu Rev Anim Biosci (2015) 3:419-45. doi: 10.1146/annurev-animal-022114-111112

49. Oddy WH, Kendall GE, Li J, Jacoby P, Robinson M, de Klerk NH, et al. The Long-Term Effects of Breastfeeding on Child and Adolescent Mental Health: A Pregnancy Cohort Study Followed for 14 Years. J Pediatr (2010) 156 (4):568-74. doi: 10.1016/j.jpeds.2009.10.020

50. Oddy WH. A review of the effects of breastfeeding on respiratory infections, atopy, and childhood asthma. J Asthma J Asthma (2004) 41:605-21. doi: 10.1081/JAS-200026402

51. Legrand D. Overview of Lactoferrin as a Natural Immune Modulator. J Pediatr (2016) 173:S10-5. doi: 10.1016/j.jpeds.2016.02.071

52. Yin C, Wong JH, Ng TB. Recent Studies on the Antimicrobial Peptides Lactoferricin and Lactoferrampin. Curr Mol Med (2014) 14(9):1139-54. doi: $10.2174 / 1566524014666141015151749$

53. Mohandas S, Pannaraj PS. Beyond the Bacterial Microbiome: Virome of Human Milk and Effects on the Developing Infant. Nestle Nutr Inst Workshop Ser (2020) 94:86-93. doi: 10.1159/000504997 
54. Lang J, Yang N, Deng J, Liu K, Yang P, Zhang G, et al. Inhibition of SARS pseudovirus cell entry by lactoferrin binding to heparan sulfate proteoglycans. PloS One (2011) 6(8):96-104. doi: 10.1371/journal.pone.0023710

55. Henrick BM, Yao XD, Nasser L, Roozrogousheh A, Rosenthal KL. Breastfeeding behaviors and the innate immune system of human milk: Working together to protect infants against inflammation, HIV-1, and other infections [Internet]. Vol. 8, Frontiers in Immunology. Front Media SA (2017) 5:1. doi: 10.3389/fimmu.2017.01631

56. Krawczyk A, Lewis MG, Venkatesh BT, Nair SN. Effect of Exclusive Breastfeeding on Rotavirus Infection among Children. Indian J Pediatr (2016) 83(3):220-5. doi: 10.1007/s12098-015-1854-8

57. Habte HH, Kotwal GJ, Lotz ZE, Tyler MG, Abrahams M, Rodriques J, et al. Antiviral activity of purified human breast milk mucin. Neonatology (2007) 92 (2):96-104. doi: 10.1159/000100808

58. Bode L, McGuire M, Rodriguez JM, Geddes DT, Hassiotou F, Hartmann PE, et al. It's alive: Microbes and cells in human milk and their potential benefits to mother and infant. Adv Nutr (2014) 36:571-3. doi: 10.3945/ an.114.006643

59. Hassiotou F, Geddes DT. Immune cell-mediated protection of the mammary gland and the infant during breastfeeding. Adv Nutr (2015) 6(3):267-75. doi: 10.3945/an.114.007377

60. Fouda GG, Martinez DR, Swamy GK, Permar SR. The Impact of IgG Transplacental Transfer on Early Life Immunity. ImmunoHorizons (2018) 2 (1):14-25. doi: 10.4049/immunohorizons.1700057

61. Hanson L, Hahn-Zoric M, Berndes M, Ashraf R, Herias V, Jalil F, et al. Breast feeding: Overview and breast milk immunology. Pediatr Int (1994) 36(5):55761. doi: 10.1111/j.1442-200X.1994.tb03246.x

62. Czosnykowska-Łukacka M, Lis-Kuberka J, Królak-Olejnik B, OrczykPawiłowicz M. Changes in Human Milk Immunoglobulin Profile During Prolonged Lactation. Front Pediatr (2020) 8:428. doi: 10.3389/ fped.2020.00428

63. Van De Perre P. Transfer of antibody via mother's milk. In: Vaccine. Philadelphia, PA, USA: Elsevier BV (2003). p. 3374-6.

64. Mazur NI, Horsley NM, Englund JA, Nederend M, Magaret A, Kumar A, et al. Breast Milk Prefusion F Immunoglobulin G as a Correlate of Protection Against Respiratory Syncytial Virus Acute Respiratory Illness. J Infect Dis (2018) 219(1):59-67. doi: 10.1093/infdis/jiy477/5068768

65. Wetzke M, Schwerk N. Respiratory syncytial virus infections. In: Pneumologe, vol. 16. US: Springer Verlag (2019). p. 232-41.

66. Gross SJ, Buckley RH, Wakil SS, McAllister DC, David RJ, Faix RG. Elevated IgA concentration in milk produced by mothers delivered of preterm infants. J Pediatr (1981) 99(3):389-93. doi: 10.1016/S0022-3476(81)80323-X

67. Hassiotou F, Hepworth AR, Metzger P, Tat Lai C, Trengove N, Hartmann PE, et al. Maternal and infant infections stimulate a rapid leukocyte response in breastmilk. Clin Transl Immunol (2009) 2(4):131-4. doi: 10.1038/cti.2013.1

68. Riskin A, Almog M, Peri R, Halasz K, Srugo I, Kessel A. Changes in immunomodulatory constituents of human milk in response to active infection in the nursing infant. Pediatr Res (2012) 71(2):220-5. doi: 10.1038/pr.2011.34
69. Melendi GA, Coviello S, Bhat N, Zea-Hernandez J, Ferolla FM, Polack FP. Breastfeeding is associated with the production of type i interferon in infants infected with influenza virus. Acta Paediatr Int J Paediatr (2010) 99(10):151721. doi: 10.1111/j.1651-2227.2010.01862.x

70. Libster R, Hortoneda JB, Laham FR, Casellas JM, Israele V, Polack NR, et al. Breastfeeding prevents severe disease in full term female infants with acute respiratory infection. Pediatr Infect Dis J (2009) 28(2):131-4. doi: 10.1097/ INF.0b013e31818a8a82

71. Ruiz L, García-Carral C, Rodriguez JM. Unfolding the human milk microbiome landscape in the omicsera. Front Microbiol (2019) 10 (JUN):644-6. doi: 10.3389/fmicb.2019.01378

72. Zimmermann $\mathrm{P}$, Curtis $\mathrm{N}$. Coronavirus infections in children including COVID-19: An overview of the epidemiology, clinical features, diagnosis, treatment and prevention options in children. Pediatr Infect Dis J (2020) 39:355-68. doi: 10.1097/INF.0000000000002660

73. Toubiana J, Poirault C, Corsia A, Bajolle F, Fourgeaud J, Angoulvant F, et al. Kawasaki-like multisystem inflammatory syndrome in children during the covid-19 pandemic in Paris, France: prospective observational study. BMJ (2020) 369:m2094. doi: 10.1136/bmj.m2094

74. Wagner CL. A Commentary on the Review Entitled, "A Scoping Review of the Human Milk Microbiome” by Groer et al. J Hum Lact (2020) 36(4):644-6. doi: 10.1177/0890334420931835

75. Protection, promotion and support of breastfeeding in Europe: a blueprint for action Promotion of Breastfeeding in Europe. Philadelphia, PA, USA (2020).

76. Verd S, Ponce-Taylor J, Ginovart G. Vertical Transmission of Severe Acute Respiratory Syndrome Coronavirus 2 from the Mother to the Infant. JAMA Pediatr (2020) 174:1003-4. doi: 10.1001/jamapediatrics.2020.2135

77. Peroni DG, Fanos V. Persistent SARS-CoV-2 RNA Positive in Feces but Negative in Breastmilk: A Case Report of COVID-19 in a Breastfeeding Patient. Acta Paediatr Int J Paediatr (2020) 109:2139-40. doi: 10.1111/apa.15417

78. Green J, Petty J, Bromley P, Walker K, Jones L. COVID-19 in babies: Knowledge for neonatal care. J Neonatal Nurs (2020) 26:239-46. doi: 10.1016/j.jnn.2020.06.005

79. Pandolfi E, Gesualdo F, Carloni E, Villani A, Midulla F, Carsetti R, et al. Does breastfeeding protect young infants from pertussis? Case-control study and immunologic evaluation. Pediatr Infect Dis J (2017) 36(3):e48-53. doi: 10.1097/INF.0000000000001418

Conflict of Interest: The authors declare that the research was conducted in the absence of any commercial or financial relationships that could be construed as a potential conflict of interest.

Copyright (c) 2021 Vassilopoulou, Feketea, Koumbi, Mesiari, Berghea and Konstantinou. This is an open-access article distributed under the terms of the Creative Commons Attribution License (CC BY). The use, distribution or reproduction in other forums is permitted, provided the original author(s) and the copyright owner(s) are credited and that the original publication in this journal is cited, in accordance with accepted academic practice. No use, distribution or reproduction is permitted which does not comply with these terms. 